\title{
Gravity enrichment of resistant gold-bearing ores
}

\author{
Gulzhan Askarova ${ }^{1, *}$, Mels Shautenov ${ }^{1}$, and Kulzhamal Nogaeva ${ }^{2}$ \\ ${ }^{1}$ Kazakh National Research Technical University named after K. I. Satpayev, 050000, Almaty, \\ Satpayev Str. 22, Republic of Kazakhstan \\ ${ }^{2}$ Kyrgyz state University, of geology, mining and development of natural resources named after \\ academician Usengazy Asanalie, 720001, Bishkek, Chui Ave., 215, Republic of Kyrgyzstan
}

\begin{abstract}
The aim of the research is the selection and justification of the combined gravity method of enrichment of refractory gold-bearing raw materials and the hydro and pyrometallurgical method of processing enrichment products based on the study of the technological properties of the feedstock and enrichment products in the mineral and raw materials complex of the deposit located on the territory of the Republic of Kazakhstan. There is a tendency to increase the imbalance between mining and also the increase in off-balance reserves of gold-bearing ores, which ultimately poses a serious problem for the development of the country's economy. Research on the development of technology for the extraction of gold from refractory ores has been performed on three samples of the Vasilkovsky stockwork deposit. The ores are persistent in the presence of arsenic (arsenopyrite) and finely divided gold, a significant part of which is in the form associated with both sulfides (mainly arsenopyrite) and rockforming minerals.
\end{abstract}

\section{Introduction}

In the mineral resource complex of the Deposit located in the territory of the Republic of Kazakhstan there is a tendency of growth of imbalance between production and growth of off-balance reserves of gold-containing ores, which ultimately poses a serious problem for the development of the country's economy. Most of the reserves of rich, easily enriched gold-containing mineral raw materials are exhausted. Kazakhstan goldextracting industry is constantly involved in the processing of new gold deposits. In most cases, the ores of these deposits belong to the category of persistent and particularly persistent. According to preliminary data, the share of these ores is more than $30 \%$ of all reserves, which means that due to the wider involvement in the operation of persistent gold and complex gold-bearing ores in the 21 st century, a significant increase in gold production can be achieved. A significant part of the reserves of indigenous gold is resistant ores, in which the gold is in a fine state in sulfides and rock-forming minerals. The particle size ranges from tens to thousandths of a micron. Gold is mainly associated with pyrite and arsenopyrite, so it does not dissolve during cyanidation at a standard

${ }^{*}$ Corresponding author: askarova_guljan@mail.ru 
grinding size of $80-95 \%$ of the class $-0.074 \mathrm{~mm}$ and even at ultrafine grinding, without the use of preparatory technology before cyanidation. Also, a preparatory stage is necessary, which improves the indicators of further extraction to acceptable values. Since the main mineral carriers of gold are sulfides and arsenopyrite, the preparation usually consist of the oxidation of a sulfide or arsenide matrix. For ores that contain active carbon, it is also necessary oxidation or passivation. Primary gold ores are called persistent if the extraction of gold from them using traditional cyanidation technology does not exceed $80 \%$. The persistence of gold is primarily due to its dispersion in sulfide minerals and arsenopyrite in an isomorphic or dispersed form, making it difficult to access the leaching solution. The second reason for persistence is the presence in the ore of significant amounts of carbonaceous matter, which is a sorbent of gold, or other natural sorbents that can Sorb noble metals from cyanide solutions, which thereby increases the loss of gold and silver with the tails of the technological process. These two factors can be manifested simultaneously, which particularly complicates the processing technology. Such ores are called double refractory ores (double refractory ores). The problem of processing these ores today is very relevant. The type of technologically resistant mineral raw materials should also include ores and concentrates that contain organometallic, cluster, colloidal and other chemical and composite compounds, also complicating the technological extraction of useful components. The prevalence of particularly resistant gold is high. The largest and most famous representatives in Russia are primary ores of the Olympiadinsky Deposit, gold sulfide ores of the May Deposit, ores of the Sukhoi Log deposits and others; abroad - BarrickGoldstrike, BarrickMercur, Cortez, Newmont, Carlin (USA), Hillgrove (Australia), Macraes (New Zealand) and others [1].

The enrichment process is a single system in which the individual elements are interconnected. High results can be achieved only with a systematic approach, which will take into account the interaction of the elements of the system, that is, in this case, a full range of processes. Gravitational enrichment is undoubtedly one of the most famous processes. It is to him that history owes the fact that gold was the first metal with which mankind was acquainted for several millennia before our era. Nature itself has taken care of this, freeing the gold from their host minerals in the beds of rivers and streams that flowed through the gold-bearing rocks, giving them such an attraction, which could not fail to draw the attention of our ancestors. With gravitational methods of enrichment, mass gold mining from placers began, after which these methods actively "stepped" into the factory technology of processing ores of indigenous deposits. Currently, gravitational concentration of gold is widely used in gold recovery factories in all countries of the world, including those that account for most of the production of this metal (China, Australia, the Russian Federation).

According to the nature of the processed raw materials, these factories are divided into 3 groups. Group 1 includes enterprises engaged in the extraction of gold and silver with it from relatively simple in technological terms quartz and quartz-sulfide ores containing noble metals mainly in cyanide-soluble form [1].

Group 2 includes ZIF processing cyanide-resistant pyrite and arsenic-pyrite ores with fine gold in sulfides, as well as ores containing sorption-active carbonaceous substance.

Finally, group 3 consists of enterprises for processing complex ores containing, along with gold and silver, heavy non-ferrous metals (copper, lead, zinc, antimony), as well as uranium. Within each group, the number of enterprises applying the processes of gravity, flotation enrichment and cyanidation is determined (Table 1,2).

However, the list of gold mining factories (GMF) presented in the tables is incomplete, nevertheless, fairly objectively reflects the current trends in the production of gold from the 
ores of indigenous deposits and the role played by each of the above technological processes, including gravity.

From the tabular data it can be seen that gravitational enrichment is practiced by more than $1 / 3$ of the analyzed GMF but gravity without combination with other processes is almost not used. For the study, the chemical composition of the studied ore was performed $[1-4]$.

Table 1. The scope of application of gravity, flotation and GMF (gold mining factories) plant [1].

\begin{tabular}{|c|c|c|c|c|}
\hline \multirow{2}{*}{ Name of indicators } & \multicolumn{4}{|c|}{ Group of enterprices } \\
\cline { 2 - 5 } & $\begin{array}{c}\text { I } \\
\text { Simpleores }\end{array}$ & $\begin{array}{c}\text { II } \\
\text { Resistantores }\end{array}$ & $\begin{array}{c}\text { III } \\
\text { Complexore }\end{array}$ & Total \\
\hline Total number of GMF & 142 & 53 & 44 & 239 \\
\hline \multirow{5}{*}{ Including the number of GMF applying: } \\
\hline \multirow{2}{*}{$\begin{array}{c}\text { gravitation } \\
\text { flotation } \\
\text { cyanidation }\end{array}$} & 42 & 17 & 19 & 78 \\
\cline { 2 - 5 } & 26 & 36 & 43 & 106 \\
\cline { 2 - 5 } & 137 & 47 & 25 & 209 \\
\hline
\end{tabular}

Table 2. Ore gravity concentration plant [1].

\begin{tabular}{|c|c|c|c|c|}
\hline \multirow{2}{*}{ Name of indicators } & \multicolumn{4}{|c|}{ Group of enterprises } \\
\cline { 2 - 5 } & $\begin{array}{c}\text { I } \\
\text { Simple ores }\end{array}$ & $\begin{array}{c}\text { II } \\
\text { Resistant ores }\end{array}$ & $\begin{array}{c}\text { III } \\
\text { Complex ore }\end{array}$ & Total \\
\hline $\begin{array}{c}\text { The number of GMF } \\
\text { applying gravity } \\
\text { concentration }\end{array}$ & 42 & 17 & 19 & 78 \\
\hline $\begin{array}{c}\text { Including: } \\
\text { as the only } \\
\text { technological } \\
\text { process }\end{array}$ & 1 & - & - & 1 \\
\hline $\begin{array}{c}\text { in combination } \\
\text { with cyanidation }\end{array}$ & 23 & - & - & 23 \\
\hline $\begin{array}{c}\text { in combination } \\
\text { with flotation } \\
\text { (without cyanidation) }\end{array}$ & 2 & 3 & 5 & 44 \\
\hline $\begin{array}{c}\text { in combination } \\
\text { with flotation } \\
\text { enrichment and } \\
\text { cyanidation }\end{array}$ & 16 & 14 & 14 & 40 \\
\hline
\end{tabular}

Ores of the Vasilkovsky deposit include arsenopyrite, pyrite, pyrrhotite, marcasite, gold, chalcopyrite, sphalerite, galena, faded ore (tennantite), bismuthine, native bismuth, lellingite, molybdenite, cubanite, bornite, antimonite, relict minerals, magnetite, apatite and 
apatite chromite, sericite, chlorite, potassium feldspar, tourmaline), quartz, carbonates (siderite, ankerite, calcite), fluorite, barite.

Table 3. Chemical composition of the samples

\begin{tabular}{|l|c|c|c|}
\hline \multirow{2}{*}{$\begin{array}{l}\text { Element, } \\
\text { the connection }\end{array}$} & \multirow{2}{*}{ Symbol } & \multicolumn{2}{|c|}{ The contents in g/t } \\
\cline { 3 - 4 } & & Sample №1 & Sample №2 \\
\hline Silicon oxide & $\mathrm{SiO}_{2}$ & 56 & 54 \\
\hline Aluminum oxide & $\mathrm{Al}_{2} \mathrm{O}_{3}$ & 20 & 25 \\
\hline Magnesium oxide & $\mathrm{MgO}$ & 1 & 1 \\
\hline Calcium oxide & $\mathrm{CaO}$ & 1 & 1 \\
\hline Common iron & $\mathrm{Fe}_{\text {com. }}$ & 6.99 & 6.68 \\
\hline Sulfur General & $\mathrm{S}_{\text {com. }}$ & - & - \\
\hline Sulphursulphide & $\mathrm{S}_{\text {sulf }}$ & 1.5 & 1.5 \\
\hline Lead & $\mathrm{Pb}$ & 0.49 & 0.48 \\
\hline Copper & $\mathrm{Cu}$ & 0.6 & 0.61 \\
\hline Zinc & $\mathrm{Zn}$ & 1.14 & 0.75 \\
\hline Arsenic & $\mathrm{As}$ & 0.15 & 0.15 \\
\hline Gold & $\mathrm{Au}$ & 3.5 & 2.3 \\
\hline Silver & $\mathrm{Ag}$ & 16.5 & 14.2 \\
\hline
\end{tabular}

Visible from the table very small amounts of lead, copper and zinc, large free gold enrichment jigging, concentration on the table is poorly extracted.

\section{Methods}

To determine the size class of the studied ore, a sieve analysis or particle size analysis have been carried out. To do this, the samples are dispersed in a dry or wet manner, depending on the size of the material and the required accuracy of the sieve analysis. The sieves are installed from top to bottom from large to small openings. The sieves have mostly square openings corresponding to the standard scale. The sample is poured onto the upper sieve and the whole set of sieves is shaken for $10-30$ minutes. The residue on each sieve is weighed to the nearest $0.01 \mathrm{~g}$ on a technical scale. Taking the sum of the masses of all classes for $100 \%$, we determine the yield of each class of fineness by dividing the mass by their total mass.

One of the most important and complex tasks of gravitational enrichment is the development of apparatuses and circuits that can successfully separate free gold particles of available fineness ranging from 10 to 50 microns materials. Evaluation of the gravity concentration of coarse ore (up to $40-60 \mathrm{~mm}$ ) performed using fractional analysis revealed the possibility of separation of ore into heavy and light fractions. Up to $25 \%$ of all gold and up to $45 \%$ of sulfur and arsenic are extracted into the heavy fraction with a density of $+2900 \mathrm{~kg} / \mathrm{m}^{3}$ with a yield of $10.2 \%$; in the heavy fraction, compared to ore, it is enriched in gold by 2.4 times in sulfur and arsenic by 4.8 times [8].

Of the high-performance devices of this kind that have become widespread in the global enrichment practice, a concentration table and a screw separator should be distinguished. A screw separator with a spiral diameter of $1500 \mathrm{~mm}$ for ore with a grain size of 10 to 50 microns. Therefore, the use of these devices in the schemes is determined by the convenience of layout, acceptable water flow rates and the system for preparing the material for enrichment. Gravity dressing of ore in the grinding cycle may release about $1.0 \%$ gravity concentrate with a gold content of $105 \mathrm{~g} / \mathrm{t}$ and recovery of $11.1 \%$.[5]

Technological schemes of processing of gold-containing ores differ in a wide variety. The choice of a particular technological scheme depends on many factors, of which the 
main are the nature of gold in the ore and above all, its size, the chemical composition of the ore, the nature of the minerals with which gold is associated, the presence in the ore of other valuable components that complicate the processing technology.

Thus, large gold during ore grinding is released from the compound with minerals, as a result of which free gold grains are easily enriched during gravity enrichment.

\section{Experimental research}

Most gold-bearing ores contain a certain amount of large free gold $(+0.1) \mathrm{mm}$, which is poorly extracted not only by flotation enrichment, but also by hydrometallurgical processing. Therefore, the preliminary allocation of its gravitational enrichment at the beginning of the process. Over the past two to three decades, the proportion of gold extracted from technologically simple gold ores, the successful processing of which is possible according to the above standard schemes, has been steadily decreasing [6]. At the same time, the share of gold extracted from such ores increases, the effective processing of which requires much more complex and developed schemes, including operations of gravitational enrichment, flotation, etc. Gold-containing ores and concentrates, the processing of which under normal conditions with gravitational and flotation methods of extraction of large gold) does not provide a sufficiently high recovery of gold or is accompanied by increased costs for individual technological operations (grinding, cyanidation, dehydration, precipitation of gold from solutions, etc.), are called persistent. The choice of the upper limit of size of crushed ore $(40 \mathrm{~mm})$ is caused by long-term researches of gravitational enrichment of ores [7-10].

Table 4. Results of the granulometric analysis of ore at consecutive reduction of the upper limit of size from 40 to $5 \mathrm{~mm}$.

\begin{tabular}{|l|c|c|c|c|c|c|}
\hline \multirow{3}{*}{ Class size, $\mathrm{mm}$} & \multicolumn{6}{|c|}{ One crushing to size } \\
\cline { 2 - 7 } & \multicolumn{2}{|c|}{40} & \multicolumn{2}{c|}{10} & \multicolumn{2}{c|}{5} \\
\cline { 2 - 7 } & \multicolumn{2}{|c|}{ Exit, \% } & \multicolumn{2}{c|}{ Exit, \% } & \multicolumn{2}{c|}{ Exit, \% } \\
\cline { 2 - 7 } & Frequent. & Total. & Frequent. & Total. & Frequent. & Total. \\
\hline More than $40 \mathrm{~mm}$ & 1.15 & 1.15 & - & - & - & - \\
\hline $20-40$ & 29.05 & 30.20 & 2.43 & 2.43 & - & - \\
\hline $10-20$ & 44.26 & 74.46 & 41.14 & 43.57 & 2.28 & 2.28 \\
\hline $5-10$ & 10.02 & 84.48 & 26.70 & 70.27 & 44.26 & 46.54 \\
\hline $2.5-5$ & 8.17 & 92.65 & 16.49 & 86.76 & 31.78 & 78.32 \\
\hline $0-2.5$ & 7.35 & 100 & 13.24 & 100 & 21.68 & 100 \\
\hline Ore & 100 & - & 100 & - & 100 & - \\
\hline
\end{tabular}

Then we observed the distribution of gold over various ore sizes.

Table 5. Results of sieve analysis and distribution of gold by size classes of quarry ore samples crushed to from 2,5 to $40 \mathrm{~mm}$.

\begin{tabular}{|c|c|c|c|c|}
\hline \multirow[t]{2}{*}{ Class size, $\mathrm{mm}$} & \multicolumn{2}{|c|}{ Exit, \% } & \multirow{2}{*}{$\begin{array}{c}\text { Gold content, } \\
\mathrm{g} / \mathrm{t}\end{array}$} & \multirow{2}{*}{$\begin{array}{c}\text { Division, } \\
\%\end{array}$} \\
\hline & $\mathrm{g}$ & $\%$ & & \\
\hline+1.25 & 78.3 & 3.9 & 10.8 & 16.49 \\
\hline$-1.25+0.8$ & 600 & 30 & 7.2 & 10.99 \\
\hline$-0.8+0.56$ & 230 & 11.5 & 5.6 & 8.55 \\
\hline$-0.56+0.40$ & 166.8 & 8.3 & 7.6 & 11.60 \\
\hline$-0.40+0.30$ & 112.7 & 5.6 & 5.6 & 8.55 \\
\hline$-0.30+0.20$ & 126.8 & 6.3 & 5.2 & 7.94 \\
\hline$-0.20+0.15$ & 51.8 & 2.6 & 6.2 & 9.47 \\
\hline
\end{tabular}


Table 5 (continued). Results of sieve analysis and distribution of gold by size classes of quarry ore samples crushed to from 40 to $2.5 \mathrm{~mm}$.

\begin{tabular}{|c|c|c|c|c|}
\hline \multirow{2}{*}{ Class size, $\mathrm{mm}$} & \multicolumn{2}{|c|}{ Exit, \% } & $\begin{array}{c}\text { Gold content, } \\
\mathrm{g} / \mathrm{t}\end{array}$ & $\begin{array}{c}\text { Division, } \\
\%\end{array}$ \\
\cline { 2 - 3 } & $\mathrm{g}$ & $\%$ & 4 & 6.11 \\
\hline$-0.15+0.1$ & 84.0 & 4.2 & 5.4 & 8.24 \\
\hline$-0.1+0.074$ & 56.1 & 2.8 & 4.8 & 7.33 \\
\hline-0.074 seeded & 73.4 & 3.7 & 3.1 & 4.73 \\
\hline-0.074 washed & 420.1 & 21.1 & 65.5 & 100 \\
\hline Total & 2000 & 100 & \\
\hline
\end{tabular}

Table 6. Results of sieve analysis and distribution of gold by size classes of ore samples from dumps, crushed to from 2.5 to $0 \mathrm{~mm}$.

\begin{tabular}{|c|c|c|c|c|}
\hline \multirow{2}{*}{ Class size, $\mathrm{mm}$} & \multicolumn{2}{|c|}{ Exit } & $\begin{array}{c}\text { Gold content, } \\
\mathrm{g} / \mathrm{t}\end{array}$ & $\begin{array}{c}\text { Division, } \\
\%\end{array}$ \\
\cline { 2 - 3 } & $\mathrm{g}$ & $\%$ & 4.2 & 16.9 \\
\hline+1.25 & 92.0 & 4.60 & 2.8 & 11.3 \\
\hline$-1.25+0.8$ & 509.8 & 25.49 & 2.4 & 9.7 \\
\hline$-0.8+0.56$ & 254 & 12.70 & 2.5 & 10 \\
\hline$-0.56+0.40$ & 183.2 & 9.16 & 4.2 & 16.9 \\
\hline+1.25 & 92.0 & 4.60 & 2.0 & 8 \\
\hline$-0.20+0.15$ & 70 & 3.50 & 1.7 & 6.8 \\
\hline$-0.15+0.1$ & 79 & 3.95 & 2.2 & 8.8 \\
\hline$-0.1+0.074$ & 61 & 3.05 & 1.7 & 6.8 \\
\hline-0.074 seeded & 83 & 4.15 & 1.2 & 4.8 \\
\hline-0.074 washed & 576 & 28.80 & 24.9 & 100 \\
\hline Total & 2000 & 100 & & \\
\hline
\end{tabular}

According to the sieve analysis shown in tables $4-6$, you can see the distribution of gold in large classes is much higher than in small classes. Table $4-6$ presents the results of rational analysis of the samples, which differ in gold content. According to the results of rational analysis of samples, the content of associated gold is: with sulfides $7-20 \%$, with rocks minerals $2.7-7.11 \%$. The amount of free gold is $20-30 \%$ when the gold content in the samples is $2.3-3.5 \mathrm{~g} / \mathrm{t}$. These data indicate the possibility of separating a certain part of the gold associated with sulfides by gravitational methods at the beginning of the technological scheme with its subsequent extraction from gravitational concentrates by other methods.

\section{Results and discussion}

On the basis of the conducted researches the mode of crushing and grinding of ore is established. Gravitational methods of enrichment are carried out according to the technological scheme gives in Figure 1. Studies have established the following: gold extracted from the enrichment products of a free particle has a fineness ranging from 10 to 50 microns, with the main part having a size less than 20 microns, which indicates that the bulk of the ore being studied is very finely divided. Such gold when enriched with jigging, concentration on the table is poorly extracted. Extraction by deposit and concentration on the table is in the range of $8.7-10 \%$, at the same time, the extraction of such gold in a centrifugal hydroconcentrator of domestic production is $56.7 \%$ with a concentration of about $280 \mathrm{~g} / \mathrm{t}$ in it.

The results of gravity enrichment methods (screw separator) are given in Table 7. 


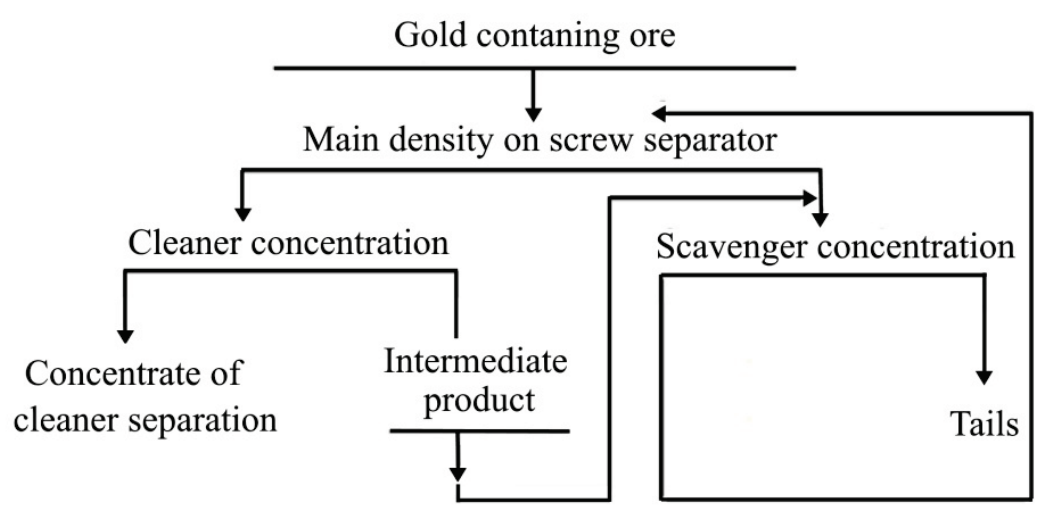

Fig. 1. Scheme of experiments on enrichment of gold-containing ore samples.

Table 7. Results of enrichment experiments on screw separator.

\begin{tabular}{|l|c|c|c|c|c|}
\hline \multirow{2}{*}{ Products } & \multicolumn{2}{|c|}{ Output } & $\begin{array}{c}\text { Gold of } \\
\text { content, } \mathrm{g} / \mathrm{t}\end{array}$ & $\begin{array}{c}\text { Weight of } \\
\text { gold, } \mathrm{g}\end{array}$ & Division, \% \\
\cline { 2 - 3 } & $\mathrm{g}$ & $\%$ & 21.5 & 0.4622 & 13.39 \\
\hline 1 concentrate & 43.0 & 2.15 & 7.6 & 0.2470 & 7.15 \\
\hline 2-concentrate & 65.0 & 3.25 & 2.9 & 2.7434 & 79.46 \\
\hline Tails & 1892.0 & 94.6 & 3.5 & 3.4526 & 100 \\
\hline Ore & 2000 & 100 & &
\end{tabular}

In recent years, great progress has been made in the technology of gravitational enrichment of gold ore. This is manifested, first of all, in the creation of new devices capable of extracting not only large but also very small particles of metallic gold, released in the process of grinding the ore.

These data indicate the possibility of separating a certain part of the gold associated with sulfides by gravitational methods at the beginning of the technological scheme with its subsequent extraction from gravitational concentrates by cyanidation methods.

Table 8. The Rational composition of the investigated samples of gold ores

\begin{tabular}{|l|c|c|c|c|}
\hline \multirow{2}{*}{$\begin{array}{c}\text { Gold } \\
\text { association } \\
\text { form }\end{array}$} & \multicolumn{2}{|c|}{ Sample №1 } & \multicolumn{2}{c|}{ Sample №2 } \\
\cline { 2 - 5 } & Content, g/t & Extraction, \% & Content, g/t & Extraction, \% \\
\hline Free gold & 6.6 & 68.75 & 0.57 & 20.96 \\
\hline $\begin{array}{l}\text { In accretions } \\
\text { with sulfides } \\
\text { and rock }\end{array}$ & 2.1 & 21.87 & 1.4 & 51.47 \\
\hline $\begin{array}{l}\text { Gold with cover } \\
\text { for mations }\end{array}$ & - & - & - & - \\
\hline $\begin{array}{l}\text { Associated with } \\
\text { sulfides }\end{array}$ & 0.64 & 6.67 & 0.48 & 17.65 \\
\hline $\begin{array}{l}\text { Associated with } \\
\text { thebreed }\end{array}$ & 0.26 & 2.71 & 0.27 & 9.92 \\
\hline Total & 9.6 & 100 & 2.72 & 100 \\
\hline
\end{tabular}

According to mineralogical analysis, sample 2 for the study is represented by granodiorites with moderate sulfide mineralization. The main ore mineral is arsenopyrite. Pyrite, pyrrhotite and very small amounts of chalcopyrite, sphalerite, Galena, faded ore, bismuthine and some others are noted in small quantities [9-16]. 


\section{Conclusion}

Concentration table and screw separators, in particular, include centrifugal concentrators (Nelson, Falcon, Knudsen, from Russian analogues - Itomak) and centrifugal jigging machines (Kelsey, Russian TSOM), in which the intensity of separation of gold particles and other minerals with lower grain density increases many times. Previously used gravity devices have been significantly improved: conventional jigging machines with vertical pulsation, multi-column concentration tables, screw separators, cone-type devices, etc. Optimal combinations of different gravity devices providing maximum gold extraction at minimum operating costs are determined. Investigations were carried out to study the distribution of gold, sulfur, and arsenic by size classes of 2-samples of gold-containing ore from the Vasilkovsky deposit. The nature of the ore and the form of occurrence of gold are determined. Gravitational ore dressing in the grinding cycle may release about $1.0 \%$ gravity concentrate with a gold content of $105 \mathrm{~g} / \mathrm{t}$ and recovering $11.10 \%$. the content of free amalgamating gold in the gravity concentrate was $36 \mathrm{~g} / \mathrm{t}$ or $3.6 \%$ of the gold content in the ore.

To improve the output of the primary concentrate, the deposit mode was changed:

- frequency of oscillation of the diaphragm 224 per minute;

- perture diaphragm 6 and $4 \mathrm{~mm}$.

Water flow rate unchanged.

A postoperative operation was performed on a concentration table.

The research was carried out within the framework of the Project GF MES RK "Research and instrumentation of the processing technology of refractory arsenic-sulfide gold-bearing ore of the Kazakhstan deposit" № 0210RK00912.

\section{Reference}

1. Mazmanyan, G.A., Bragin, V.I. (2013). Uluchshenie izvlecheniya metalla iz osobo stojkoj zolotosulfidnoj rudy. Tomsk: Publishing House of Tomsk Polytechnic University

2. Lodejshchikov, V.V. (2005). Zolotodobyvayushchie zavody mira: Analiticheskij obzor. Irkutsk: Irgiredmet

3. Carkov, V.A. (2004) Opyt zolotodobyvayushchih predpriyatij mira. Moskva: Ruda i metally

4. Aleksandrova, T.N., Romashev, A.O., Semenihin, D.N. (2015). Mineralogotekhnologicheskie aspekty i perspektivnye metody intensifikacii obogashcheniya sul'fidnyh zolotosoderzhashchih rud. Metallurg, 4

5. Aleksandrova, T.N., Cyplakov, V.N., Aksenov, B.V., Romashev, A.O., Semenihin, D.N. (2015). Tekhnologii udaleniya sorbcionno-aktivnyh uglerodistyh veshchestv iz stojkih zolotosul'fidnyh rud i koncentratov Majskogo mestorozhdeniya, Obogashchenie rudy, 4

6. Razrabotka novyh kombinirovannyh tekhnologij $i$ sovershenstvovanie sushchestvuyushchih tekhnologij pererabotki trudnoobogashchennyh rud. Otchet o nauchno-issledovatelskoi robote. No 0109101490. KazNTU, 2009

7. Issledovanie $i$ apparatnoe proektirovanie tekhnologii pererabotki stojkoj mysh'yaksul'fidnoj zolotosoderzhashchej rudy kazahstanskogo mestorozhdeniya. Otchet ob issledovanii No 0110RK00366. KazNTU, 2010

8. Chugaev, L.V. (ed.) (1987). Metallurgiya dragocennyh metallov. Moskva: Metallurgiya

9. Kotlyar, Yu.A., Meretukov M.L. (2002) Metallurgiya blagorodnyh metallov. Moskva: Metallurgiya

10. Meretukov I.N., Orlov A.M. (1991). Metallurgiya blagorodnyh metallov. Zarubezhnyj opyt. Moskva: Metallurgiya 
11. Ladejshchikov, V.V. (1968). Izvlechenie zolota iz upornyh rud i koncentratov. Moskva: Nedra

12. Ladejshchikov, V.V. (1999). Tekhnologiya izvlecheniya zolota i serebra iz upornyh rud. Irkutsk: Irgiredmet

13. Zelenov, V.I. (1978). Metody issledovaniya zolotosoderzhashchih rud. Moskva: Nedra

14. Nalimov, V.V., Chernova, N.A. (1965). Statisticheskie metody planirovaniya ekstremalnyh eksperimentov. Moskva: Nauka

15. Shohin, V.N., Lopatin, A.G. (1993). Gravitacionnye metody obogashcheniya poleznyh iskopaemyh. Moskva: Nedra

16. Rajvich, I.D. (1985). Gravitacionnoe obogashchenie droblenyh rud cvetnyh metallov $i$ raschet rezultatov ih gravitacionnogo obogashcheniya. Alma-Ata 